\title{
Kazakh Academy scientists face party leaders' fury
}

\section{London}

THE former First Secretary of the Communist Party of Kazakhstan, Dinmukhamed Kunaev, whose replacement last December by an ethnic Russian, Gennadii Kolbin, triggered two days of nationalist disturbances in Alma-Ata, faces a party inquiry on charges that include corruption, nepotism and "ethnic favoritism". This is the second step in his public disgrace (he was expelled from the All-Union Politburo in January), and there is already speculation that it may end in a formal trial. Similar allegations have also been levelled aginst the scientific and scholarly community of the republic. The Minister of Higher Education, Kupzhasa Naribaev, has resigned after publicly acknowledging his faults, the leadership of the Academy of Sciences of the Kazakh SSR has been severely criticized by party leaders in Moscow, the former head of the science and education department of the Kazakh Central Committee has been severely reprimanded and a shake-up of the universities is under way.

The demonstrations began with students from Alma-Ata University taking to the streets. According to some reports, the banners carried by the demonstrators ranged from "Kazakhstan for the Kazakhs!" and "Kolbin go home!" to demands for a separate representation for Kazakhstan at the United Nations, and even for union of Kazakhstan with China.

The ethnic situation in Kazakhstan is complex. Immigration (often involuntary) from the European territories of what is now the USSR goes back to the nineteenth century, while in the 1950 s the "virgin lands" policy of Nikita Khrushchev brought in a new wave of non-Kazakhs. As a result, Russians outnumber Kazakhs by 41 per cent to 36 per cent of the republic's population, with the remaining 23 per cent made up of some 20 other Soviet nationalities. But, under Naribaev, an unauthorized policy of positive discrimination in favour of ethnic Kazakhs had been in operation. Soon after the disturbances,

\section{Hocus pocus}

THERE seems to be in wide circulation a letter purporting to be from Nature and referring to a paper entitled "Neoplasms as uncontrolled regenerative hyperplasia" by Cris Garcia Sarmiento (deceased).

We should like to make it clear that this letter is a hoax, that we have no knowledge of either the paper or the author, and that other organizations as well as ourselves have been victims of this hoaxer.

Editor, Nature. the Soviet media noted that the student ringleaders came for the most part from southern Kazakhstan, where there is least ethnic mixing. From this area, too, came ex-minister Naribaev, and so, it appears, do six of the ten rectors of higher educational establishments in Alma-Ata.

The Academy of Sciences of the Kazakh SSR was also affected by the same failings, according to a report by the party control committee of the Central Committee in Moscow. The committee found that the academy had failed to ensure "the correct representation of scientists of different nationalities" among its members, that there was an atmosphere of "irresponsibility, obsequiousness, mutual flattery and total licence" and that the academy had wasted state funds on "ostentatious mass events", receptions, banquets and gifts to visiting notables.

Even worse, it had failed to carry out its scientific duty as coordinator of research and in the acceleration of scientific progress in the republic. Within the academy's research institutes, the control committee found, the standard of fundamental research had fallen considerably, the amount of original development work had declined, no licences had been sold and 45 per cent of the "solutions" produced turned out to be neither innovative nor useful.

None of the academy institutes had joined the new "scientific and technical complexes" in the Soviet Union to obviate bureaucratic delays in technical innovation. Nepotism and local preference had

\section{Super conductivity} New Delhi

A TEAM of researchers at the Tata Institute of Fundamental Research in Bombay and the Bhabha Atomic Research Centre at nearby Trombay claims to have demonstrated the onset of superconductivity in a synthetic oxide at a temperature of $120 \mathrm{~K}$ as well as zero electrical resistance at $90 \mathrm{~K}$. The team says that it has thus surpassed the record of superconductivity at $82 \mathrm{~K}$ set by a group led by C.W.Chu at the University of Houston (see Nature 325, 756; 1987).

Although the materials used by the two groups are very similar, the Indian team claims that their success in finding a higher transition temperature arises from "sample stoichiometry, heat treatment and preparation technique". The team used samples of yttrium/strontium/barium copper oxide which were annealed in an atmosphere of oxygen and powdered and cast into disks of 8-mm diameter. A month ago, the team found zero electrical resistance in a similar compound with lanthanum instead of yttrium. K.S.Jayaraman

led to the appointment to senior scientific posts of poorly trained and "morally lax" people.

The main responsibility for these shortcomings was attributed by the control committee to the former president of the academy, Askar Kunaev, who was replaced last year. During his term of office, said the report, Kunaev "crudely flouted the principles of collective leadership", ignored critical observations and advice from the All-Union Academy in Moscow, drank to excess and often failed to come to work or to deliver important speeches. Vera Rich

\section{SERC admits funding crisis with no respite in the years ahead}

\section{London}

THE Science and Engineering Research Council (SERC) has formally admitted that the new salary increases agreed with academic staff last month will have a dramatic effect on its research grant budget. The new salaries will cost an extra $£ 7.8$ million in the year beginning 1986 and the following year will rise to $£ 10$ million or about 'one-tenth of the annual research grant expenditure'.

SERC is concerned that the full weight of these increases must be borne by its current budget. A similar shortfall of some $£ 20$ million because of the increase in the European Organization for Nuclear Research (CERN) due to currency fluctuation, provoked the council to apply this year to the Advisory Board for the Research Councils (ABRC) for extra funds.

The disclosures are outlined in the council's new three-year plan, The forward Look, 1988/89 to 1990/91 published last week, which concludes that: "There are important areas of basic and strategic work which Council will not be able adequately to exploit".

The announcement of the SERC shortfall coincides with statements made by the organization called Save British Science which has called government attention to a deepening crisis within the research councils. Scientists are uncertain, they claim, whether their current applications will even be considered, and are fearful that their work will be "arbitrarily terminated".

Meanwhile, a working group commissioned by the government will advise on applications of defence research and development to the commercial sector. Bill Johnstone 